\title{
Going Native: Can Consumers Recognize Native Advertising? Does it Matter?
}

\author{
David A. Hyman, David Franklyn, Calla Yee, \\ and Mohammad Rahmati*
}

19 YALE J.L. \& TECH. 77 (2017)

\begin{abstract}
Native advertising, which matches the look and feel of unpaid news and editorials, has exploded online. The Federal Trade Commission has long required advertising to be clearly and conspicuously labeled, and it recently reiterated that these requirements apply to native advertising. We explore whether respondents can distinguish native advertising and "regular" ads from unpaid content, using 16 native ads, 5 "regular" ads, and 8 examples of news/editorial content, drawn from multiple sources and platforms. Overall, only 37\% of respondents thought that the tested examples of native advertising were paid content, compared to $81 \%$ for "regular" advertising, with variation by platform, advertiser, and labeling. Modest labeling changes materially increased the number of respondents that correctly recognized that native ads are paid content - but even these improved results fell well short of those for "regular" advertising. We also explored labeling preferences and self-reported concern about native advertising. Our findings indicate that native advertising involves a significant risk of deception which self-regulation has not addressed.
\end{abstract}

\footnotetext{
Hyman is Professor of Law, Georgetown University. Franklyn is Professor of Law, University of San Francisco. Yee is an associate at Kilpatrick, Townsend \& Stockton. Rahmati is an associate professor at Sharif University.

We appreciate the comments and feedback we received when this paper was presented to FTC Bureau of Consumer Protection Staff; at the 2015 University of San Francisco McCarthy Institute Trademark Symposium; and at the 2016 Stanford IPSC Conference. In particular, we appreciate the comments provided by Barton Beebe, Laura Heymann, Mark McKenna, Lisa Ramsey, and Rebecca Tushnet.
} 


\section{TABLE OF CONTENTS}

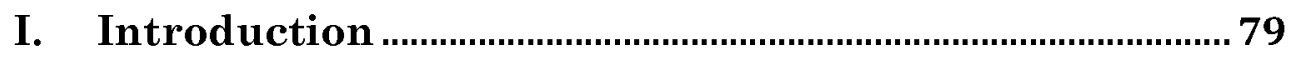

II. The Evolution of Native Advertising............................... 83

III. Past Research, Industry Guidelines, And the Law of

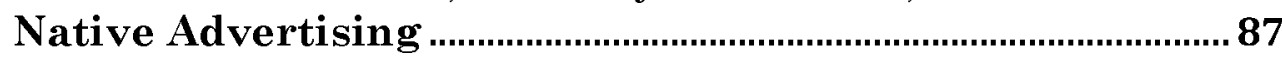

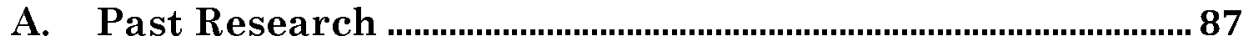

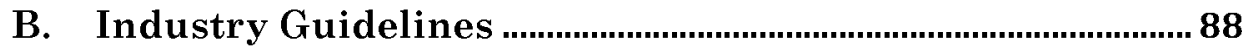

C. The Law of Native Advertising ................................................ 89

IV. Our Methodology and Findings.......................................91

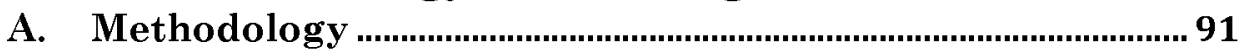

B. Overview of Findings ........................................................... 91

C. Effectiveness of Labeling and Pop-Ups .................................. 95

D. Attitudes Regarding Advertising …………...........................102

E. Do Users Learn From Experience? ......................................103

F. Regression Analysis ..............................................................103

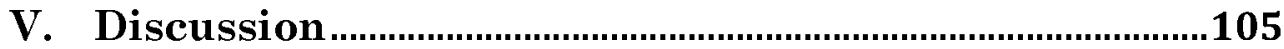

A. The Logic of Native Advertising ..........................................105

B. Do Consumers Know That Native Advertising Is Paid? 106

C. Trust and Integrity ..........................................................106

D. Does Intent Matter?...............................................................108

E. Self-Identity and the Media Ecosystem ...............................109

F. Remedies................................................................................110

G. Robustness/Further Research...............................................110

VI. Conclusion .......................................................................111 
"WWhen I explain what I do to friends outside the publishing industry, the first response is always "so you are basically tricking users into clicking on ads?"1

\section{INTRODUCTION}

For more than a century, advertisers have used "advertorials" to promote a wide array of products and companies. The latest incarnation of advertorials is "native advertising," which closely matches the look and feel of unpaid news and editorials, but it is actually paid content. Native advertising did not attract much popular attention until January, 2013, when The Atlantic put a "sponsored article" for the Church of Scientology on its web site, hailing the "milestone year" that Scientology had experienced. ${ }^{2}$ The "article," which was actually a paid ad, had the same look and feel as Atlantic's editorial content. The only indication that the "article" was an ad was a small yellow label that said "Sponsor Content." The piece triggered a major backlash, ${ }^{3}$ including a scathing parody in the Onion. ${ }^{4}$ The Atlantic quickly withdrew the "article," apologized to its readers, and adopted stricter policies regarding native advertising. ${ }^{5}$

This episode did little to dampen the rise of native advertising. Indeed, in the past few years, native advertising has become a pervasive feature of the print and online media environment. ${ }^{6}$ Native advertising

Kunal Gupta, 4 big threats native advertising faces in 2015, VentureBeAT (Oct. 24, 2014, 6:30 PM), https:/perma.cc/YHT4-P2WP. See also Tanzina Vega, Sponsors Now Pay for Online Articles, Not Just Ads, N.Y. Times, Apr. 7, 2013 (arguing the average reader doesn't "realize they are being fed corporate propaganda.")

2 Jim Edwards, Here's The Scientology 'Sponsored Content' Story That The Atlantic Doesn't Want You To See, Business Insider (Jan. 15, 2013, 9:04 AM), https://perma.ce/4ZGG-M4F9.

3 See, e.g., Jared Keller, The Atlantic, the Church of Scientology, and the Perils of Native Advertising, BLOOMBERG (Jan. 16, 2013, 11:36 AM), https://perma.cc/WLR8-WXVE; Josh Voorhees, The Atlantic Yanks Scientology Advertorial After Outcry, SLATE (Jan. 15, 2013, 11:26 AM), https://perma.cc/K8XU-BCU6; Julie Moos, The Atlantic publishes then pulls sponsored content from Church of Scientology, POYNTER (Jan 15, 2013), https:/perma.cc/7HAE-BDVZ.

4 SPONSORED: The Taliban Is A Vibrant And Thriving Political Movement, The Onion (Jan. 15, 2013), https://perma.cc/XLQ5-M58C.

5 See Lucia Moses, After Scientology Debacle, The Atlantic Tightens Native Ad Guidelines: Sponsored content will become more prominent on the site, ADWEEK (Jan. 30, 2013 12:44 PM), https://perma.cc/Q63Y-34JF.

6 See Dan Shewan, Native Advertising Examples: 5 of the Best (and Worst), Word Stream Blog, https:/perma.cc/367Y-P7V9 (last updated Nov. 29, 2016) ("These days, native advertising is everywhere - and its getting harder and harder to spot."); Farhad Manjoo, Why 'Native Ads' Muddy the Water For Web Surfers, WaLl ST. J., Nov. 20, 2013 ("The widespread adoption of native advertising is ushering in a Web where paid and unpaid messages increasingly blend together and where there are only the faintest 
accounted for $\$ 4.7$ billon in ad spending in $2013,{ }^{7}$ and was estimated to grow to $\$ 7.9$ billion in $2015,{ }^{8} \$ 21$ billion in $2018,{ }^{9}$ and $\$ 53$ billion in 2020.10

Mainstream media outlets, including The New York Times, The Wall Street Journal, and Forbes have set up in-house special units to develop and market native advertising campaigns. ${ }^{11}$ Despite the 2013 meltdown, native advertising now accounts for $75 \%$ of ad revenue at The Atlantic. ${ }^{12}$ At the New York Times, native advertising "accounted for $18 \%$ of digital advertising revenue in the third quarter [of 2015], up from $10 \%$ in the second quarter. ${ }^{13}$ At Facebook, $83 \%$ of its ads are native advertising, and more than $50 \%$ of its advertisers use native advertising exclusively. ${ }^{14}$ Because native advertising circumvents ad blocking software, it is likely to become an even more prominent part of the advertising landscape, particularly in the mobile setting. ${ }^{15}$

The rise of native advertising has prompted vehement criticism. When Forbes puts a native ad for Fidelity on the cover of its print edition, critics accused it of breaking "one of the last remaining taboos in [the] industry." 16 The editor of The Wall Street Journal referred to native advertising as a "Faustian pact." 17 Comedian John Oliver

visual distinctions between content that carriers a commercial message and content that doesn't.")

7 Mark Hoelzel, The Native-Advertising Report: Spending Trends, Format Breakdowns, and Audience Attitudes, BI INTELligence (May 20, 2015, 5:04 PM), https:/perma.ce/5HTC-YMB3.

8 Id

9 Id.

10 David Cohen, Native Advertising Dominates Facebook Audience Network (Study), SocialTimes (Apr. 5, 2016, 9:00 AM), https:/perma.cc/EX3Y-7PPL.

11 The Wall Street Journal's unit is called the "WSJ. Custom Studios." WSJ. CUSTOM STUDIOS, https:/perma.cc/N5X6-U8CX (last visited Nov. 29, 2016).

12 Yuyu Chen, How sponsored content drives more than 60 percent of The Atlantic's ad revenue, DIGIDAY (Mar. 28, 2016), https:/perma.cc/5X2N-XBUF.

13 Margaret Sullivan, As Print Fades, Part 4: Native Advertising on the Rise, N.Y. TIMES: Public Editor's Journal (Nov. 12, 2015, 8:00 AM), https://perma.cc/5WZU-N4HY.

14 See supra note 10.

15 Id. See also Manjoo, supra note 6 (noting importance of native ads "as Web users spend more time on phones and tablets. .."); Christina Hajszan, Is Native Advertising the Answer to Increasing Ad Avoidance? BRAND BA.SE (Oct. 13, 2016), https:/perma.cc/D4D5-CDS6.

16 Michael Sebastian, Forbes Puts Native Ad for Fidelity on Its (Actual) Cover: Another Taboo Broken, AdvertisingAge (Feb. 13, 2015), https:/perma.cc/B5PR-YNA8; See also AMERICAN SOCIETY OF MAGAZINE EDITORS, Editorial Guidelines, https://perma.cc/SXU7ZTXW (last visited March 17, 2015) (the number one rule for the ASME is "Don't Print Ads on Covers").

17 Joe Pompeo, 'Wall Street Journal' Editor Gerard Baker decries native advertising as a 'Faustian pact,' POLITICOMEDIA (Sept. 25, 2013, 10:54 AM), https://perma.cc/SXT39.J6Y. 
described native advertising and the justifications that had been offered for it as "repurposed bovine waste" - more colloquially referred to as "bullshit." 18 Others have worried about the impact of native advertising on the integrity and credibility of publishers and media platforms, ${ }^{19}$ and called for more aggressive regulation. ${ }^{20}$

Proponents have defended native advertising as substantive content that also provides an economic lifeline for a declining industry i.e., a way the media can "put content [it] can monetize in the hands of the right audiences." 21 For example, Forbes executives thought it was "appropriate for Fidelity to be called out on the cover just like any other great piece of content would be." 22 Proponents also argue that it is not in the interest of publishers or platforms to deceive their users, erode consumer trust, or compromise the wall between editorial content and advertising. ${ }^{23}$ Instead, native advertising is a good way for a publisher to "share[ its storytelling tools with a marketer." 24

How is native advertising regulated? As we discuss below, there are industry guidelines, although they mostly seem to be observed in the breach. The Federal Trade Commission ("FTC") held a workshop on native advertising in 2013, ${ }^{25}$ and issued regulatory guidance in 2015 , based on its statutory mandate to prevent unfair and deceptive trade practices. ${ }^{26}$ The FTC's regulatory guidance makes it clear that it will hold native advertising to the same standard as all other advertising meaning that it must be "clearly and conspicuously" labeled. ${ }^{27}$

Erik Wemple, HBO's John Oliver: Native advertising is 'repurposed bovine waste,' THE WASHINGTON POST (Aug. 4, 2014), https://perma.ce/Q6R7-WUXC

19 See Lili Levi, A "Faustian Pact"? Native Advertising And The Future of The Press, 57 Arizona L. Rev. 647 (2015).

20 Id. See also Amar C. Bakshi, Why And How To Regulate Native Advertising in Online News Publications, 4 U.BaLT. J. Media L. ETHICs 4 (2015).

21 Lewis DVorkin, Inside Forbes: The Next Step in our BrandVoice Native Ad Platform, FORBES (Feb. $\quad 17, \quad 2015, \quad 9: 23 \quad$ AM), http:/www.forbes.com/sites/lewisdvorkin/2015/02/17/inside-forbes-the-next-step-in-ourbrandvoice-native-ad-platform/\#78a815abe842.

22 Sebastian, supra note 16.

23 See Anthony B. Ponikvar, Note, Ever-Blurred Lines: Why Native Advertising Should Not Be Subject to Federal Regulation, 93 N.C. L. Rev. 1187 (2015).

24 Interactive Advertising Bureau, Meredith Levien (with Terry Kawaja) on Good Native Advertising, YOUTUBE (FEB. 11, 2014), https://perma.cc/69HA-BDBX.

25 Fed. Trade Comm'n, Blurred Lines: Advertising or Content? An FTC Workshop on Native Advertising (Dec. 4, 2013), https://perma.cc/ABW8-4YKS [hereinafter FTC Workshop on Native Advertising].

26 Fed. Trade Comm'n, Native Advertising: A Guide for Businesses (Dec. 2015), https://perma.ce/377E-TQ3D; Fed. Trade Comm'n, Enforcement Policy Statement on Deceptively Formatted Advertisements (Dec. 22, 2015), https://perma.ce/5FLT-U9L3.

27 Id. at 3 ("The Commission concluded that a clear and conspicuous disclosure that the column was an advertisement was necessary to prevent consumers from being 
Consistent with this guidance, the FTC recently settled a deception case against Lord \& Taylor for its participation in a native advertising campaign. ${ }^{28}$ The FTC has also settled multiple cases involving ginned up favorable online reviews. ${ }^{29}$

One study of thousands of native ads from 2015 found that inadequate labeling was the rule. ${ }^{30}$ Only one-third of publishers were labeling those ads in a way that was consistent with FTC guidelines. Analyzed at the level of native ads,

around 54 percent were labeled with the words "sponsor" or "sponsored." The second most popular label last year was "promoted," which was listed on around 12 percent of all native ads reviewed. Less than 5 percent of ads included phrases like "brought to you by," "partner content" or "content by." Another 12 percent of ads surveyed included no label at all. ${ }^{31}$

Thus the most popular label was "sponsor or sponsored," used on 54\% of the native ads.

Despite the pervasiveness of native advertising, not much is known about whether consumers are actually confused or deceived - let alone the extent to which consumer confusion and deception varies by advertiser and platform. These problems are compounded by the wide array of labels currently used to identify native advertising, including "sponsored content," "paid posts," "partner content," "promoted by," "brand publisher," and the like.

Using an online survey, we examine whether consumers can differentiate native ads and "regular" ads from unpaid content. We test sixteen different examples of native advertising and various controls, drawn from multiple platforms and advertisers. We also explore

deceived.")

28 Fed. Trade Comm'n, Press Release, Lord \& Taylor Settles FTC Charges It Deceived Consumers Through Paid Article in an Online Fashion Magazine and Paid Instagram Posts by 50 "Fashion Influencers" (Mar. 15, 2016), https://perma.cc/85KS-DGB4.

29 See Fed. Trade Comm'n, Warner Bros. Settles FTC Charges It Failed to Adequately Disclose It Paid Online Influencers to Post Gameplay Videos (July 11, 2016), https:/perma.ce/XM5C-6HW3; Fed. Trade Comm'n, FTC Approves Final Order Prohibiting Machinima, Inc. from Misrepresenting that Paid Endorsers in Influencer Campaigns are Independent Reviewers (Mar. 17, 2016), https://perma.cc/WX6U-3U7E; Fed. Trade Comm'n, FTC Stops Automobile Shipment Broker from Misrepresenting Online Reviews (Feb. 27, 2015), https:/perma.cc/QTV4-SRSL; Fed. Trade Comm'n, Firm to Pay FTC $\$ 250,000$ to Settle Charges That It Used Misleading Online "Consumer" and "Independent" Reviews (Mar. 15, 2011), https:/perma.cc/HTS5-F2GZ.

30 See Marty Swant, Publishers Are Largely Not Following the FTC's Native Ad Guidelines, ADWEEK (Apr. 6, 2016, 1:55 PM), https:/perma.cc/KJ5R-KC3L. 
labeling preferences and self-reported assessments of native advertising.

Part II provides background on the evolution of paid content (including native advertising) in various media channels. Part III reviews industry guidelines, past research, and the law of native advertising. Part IV explains our methodology and presents our results. Part $\mathrm{V}$ discusses the implications and limitations of our findings. Part VI concludes.

\section{The Evolution OF NATIVE Advertising}

Paid advertising that mimics unpaid content is not new. "Advertorials," which appear to be unpaid content, but are actually advertising, first appeared in the late 1800s. A famous advertorial for Cadillac appeared in the Saturday Evening Post in $1915 .{ }^{32}$ During the 1930 s-1950s, advertisers sponsored radio and TV broadcasts - initially as general image enhancers, and subsequently to promote specific products. ${ }^{33}$ Proctor \& Gamble used radio serials to advertise Camay soap, ${ }^{34}$ and General Foods sponsored one of the first "branded' television shows, Today's Children. ${ }^{35}$ Camel cigarettes sponsored the Camel News Caravan, a 15 minute news program that aired on $\mathrm{NBC}$, from 1949-1956. In 1951, The Atlantic announced that it would include advertorials, and began with a five page series sponsored by the American Iron \& Steel Institute. ${ }^{36}$ Mutual of Omaha sponsored Wild Kingdom. ${ }^{37}$ The rise of television resulted in "infomercials." ${ }^{38}$ And, anyone that watches public television or listens to public radio knows that advertisers routinely "underwrite" programming.

Native advertising was the logical next step in these trends but the rise of the Internet dramatically increased the number of

See Jovce Manalo, A Brief History of Native Advertising, CONTENTLY (Mar. 28, 2014), https://perma.ce/PX5D-R9HW; The RCA Story, RCA, https://perma.ce/G63C-GDGP (last visited Nov. 29, 2016); Robert C. Allen, Speaking of Soap Operas 102-103 (The University of North Carolina Press 1985). See also David Tokheim, The 5 Myths of Native Advertising, "Heard ON THE WEB" MEdia InTELLigenCe, https://perma.cc/E6LW3KEY (last visited Nov. 29, 2016).

34 ALLEN, supra note 33, at 108; see also Manalo, supra note 33.

35 ALLEN, supra note 33 , at 113.

36 Business Is the Public's Interest, The Atlantic (1932-1971) (Boston). Dec. 1951, at 19. 24.

37 Mutual of OMahA'S WiLd KingDom, https://perma.cc/6V98-Z2CK (last visited Nov. 29, 2016).

38 Manalo, supra note 33 . 
venues into which such content could be inserted, and the ability to precisely target potential customers. As we describe above, there has been dramatic growth in the number of these ads, and the platforms on which they appear.

What exactly is native advertising? Although the term is widely used, there is no authoritative definition. For example, is it "invisible advertising," 39 that is "in many ways indistinguishable from the journalistic content along which [it] appear[s]" ?"40 Is it "paid ads that are so cohesive with the page content, assimilated into the design, and consistent with the platform behavior that the viewer simply feels that they belong" ? ${ }^{41}$ Is it advertising that reflects the "native tongue of the platform," ${ }^{2}$ because it is indistinguishable from the unpaid content in layout, form, and tone? ${ }^{43}$ Is it just updated marketing jargon for an advertorial?" Is it advertising that "minimizes disruption to a consumer's online experience by appearing in-stream"? ${ }^{45}$ Does it mean whatever publishers want it to mean? ${ }^{46}$

More skeptical commentators describe native advertising as content that "is designed to fool readers into thinking they've read a normal news story, written truthfully and independently, when in reality it's tainted by the agenda of the brand that paid for it." 47 Similarly, another commentator noted that native advertising is "a tactic meant to draw readers to ads by making them more or less resemble the surrounding editorial content. A bit of reader confusion over what's an ad is inherent." 48 The quote that leads this article points to a more scathing conclusion: native advertising is not about just "a bit

39 Robert Rose, Why Native Advertising is Neither, CONTENT MARKETING InstituTE (Aug. 26, 2013), https://perma.ce/5VYK-4SGM.

40 Sam Slaughter, Can Content Marketing Save Journalism?, MashaBle (Mar. 18, 2013, 9:07 PM), https:/perma.cc/44FY-SUTJ.

41 Interactive Advertising Bureau, The Native Advertising Playbook, 3 (Dec. 4, 2013), https:/perma.ce/9G7N-3JC2 .

42 David Tokeheim, The 5 Myths of Native Advertising, SAY DaILY (Nov. 29, 2012), https://perma.cc/H8C9-WMXB?type=image..

43 Sean Strother, Adapting to the Evolution of Native Ads, DiREct MARKETING NEws (Nov. 25, 2013), https://perma.cc/SUA9-95Q7 ("Like print advertorials, online native ads are specifically designed to appear in the same manner as organic content.")

44 Mitch Joel, We Need A Better Definition of 'Native Advertising,' HaRvard Bus. Rev. BLOG (Feb. 12, 2013), https://perma.cc/KF68-MSF3.

45 Colin Campbell \& Lawrence J. Marks, Good Native Advertising Isn't A Secret, 58 Bus. HORIZONS 599 (2015)

46 Id

47 David Holmes, There's only one way to stop native advertising from ruining journalism: Embrace it, PANDODAILY (Dec. 10, 2014), https:/perma.cc/L3JX-V4B4.

48 Michael Sebastian, New York Times Tones Down Labeling on Its Sponsored Posts, ADVERTISINGAGE (Aug. 5, 2014), http://adage.com/article/media/york-times-shrinkslabeling-natives-ads/294473/ 
of reader confusion," but is built on a foundation of intentional deception. ${ }^{49}$ Stated differently, it is not an accident that the "secret behind really good native advertising is that no one is really aware of it." 50

Websites vary widely in how much native advertising they present; the prominence with which the native advertising is displayed; and how the ads are labeled. And, the same platform can change its policies regarding native advertising over time. When The New York Times first introduced native advertising in January, 2014, paid posts were surrounded by a thick blue border that was labeled at the top as "paid for and posted by [the sponsor]," along with multiple logos for that sponsor. ${ }^{51}$ But, over time, The New York Times "shrunk the labels that distinguish articles bought by advertisers from articles generated in its newsroom and made the language in the labels less explicit." 52 Most of these labeling and formatting changes made The New York Times' "native ads less obvious to consumers." 53

Of course, The New York Times is not the only media platform using native advertising. Forbes has "Brand Voice."54 Facebook has "Sponsored Posts." 55 The Washington Post has "Sponsor Generated Content." ${ }_{56}$ The New Yorker has "Sponsor Content." 57 BuzzFeed has

49 See supra note 1 , and accompanying text.

50 Campbell \& Marks, supra note 45 , at 600

51 Sebastian, supra note 48. See also Kim Anderson, Will Millennials Ever Completely Shun the Office?, N.Y. TIMEs (Jan. 8, 2014), https:/perma.cc/H3SK-UM4Y. The Netflix ad can be viewed at Melanie Deziel, Women Inmates: Why The Male Model Doesn't Work, N.Y. Times, https://perma.cc/9E8M-BHXW (last visited Nov. 29, 2016)

52 Augie Ray, New York Times Admits Its Native Advertising Violates FTC Rules, EXPERIENCE: The BLOG (Aug. 15, 2014), https:/perma.cc/4MWN-9NJ4.

53 Tessa Wegert, Did Native Advertising Just Have the Best Summer Ever?, CLICKZ (Sept. 4, 2014), https:/perma.cc/5VV7-CFSD. One commentator suggested that the New York Times made these changes because "[s]everal marketers have bristled at all the labeling, suggesting it turned away readers before they had a chance to judge the content based on its quality." Sebastian, supra note 48. The head of native advertising at the New York Times argued in response that their new "sticky" "Paid Post" border, makes it more obvious that the content is a paid ad. Joe Lazauskas, How the New York Times Built Its Content Marketing Machine, ConTENTLY (Oct. 30, 2014), https:/perma.cc/NM8N-WF3D. Of course, it is ultimately an empirical question whether any given formatting and labeling changes make it more or less apparent that the associated content is a paid ad.

54 BrandVoice, FORBES MEDIA, https:/perma.cc/6NNH-D62F. See also DVorkin, supra note 21 (discussing BrandVoice).

55 Kapil Jekishan, Facebook Ads vs Promoted Posts: A Side-by-Side Comparison, SOCIALMOUTHS, https://perma.cc/5B98-5E5H.

56 Michael Sebastian, The Washington Post Starts Selling Native Ads for Print, AD AGE (Aug. 27, 2013), https://perma.cc/FSK3-Z43G..

57 Josh Sternberg, The New Yorker Goes Native, DIGIDAY (Sep. 10, 2013), https:/perma.cc/UQ92-ELEZ. 
"BuzzFeed Partner." 58 Indeed, most of Buzzfeed's revenue is attributable to native advertising. ${ }^{59}$

Social media has created new platforms on which native advertising can be deployed. One recent controversy, that ended up on the front page of The New York Times, focused on whether the Kardashian/Jenner sisters had violated the law, by failing to adequately disclose that they were being paid for the product testimonials they were posting on Instagram. ${ }^{60}$ In response to similar episodes involving other celebrities, the FTC has indicated it will crack down on such practices. ${ }^{61}$

How effective is native advertising? Facebook Audience Network claims that "users engage with native ads 20 percent to 60 percent more than they do with standard banner ads, and native ads result in user retention up to three times higher." ${ }^{2}$ BuzzFeed boasts that the click-through rate on native advertising on its site is approximately $10 \mathrm{x}$ the industry standard for banner ads. ${ }^{63}$ The dramatic growth in the use of native advertising also indicates that everyone involved thinks that native advertising is more effective than the alternatives.

Users can also help magnify the effect of native advertising campaigns. A BuzzFeed campaign for Toyota ("14 coolest Hybrid Animals") resulted in thousands of Facebook shares and tweets. ${ }^{64}$ Netflix's native ads in the New York Times and Wired generated industry chatter and tens of thousands of "shares" through social media. ${ }^{65}$ Other native advertising campaigns have gone viral as well. ${ }^{66}$ Lists, N.Y. TiMES (Aug. 10, 2014), https://perma.cc/H7SH-H6PS ("[M]ost of BuzzFeed's revenue is derived from BuzzFeed Creative, the company's 75-person unit dedicated to creating for brands custom video and list-style advertising content that looks similar to its own editorial content."); Josh Constine, BuzzFeed's Future Depends On Convincing Us Ads Aren't Ads, TECHCRUNCH (Aug. 12, 2014), https://perma.ce/7WEP-Q78F ("BuzzFeed makes the majority of its money on ads that pretend to be content. ..").

60 Sapna Maheshwariaug, Endorsed on Instagram by a Kardashian, but Is It Love or Just an Ad?, N.Y. Times (Aug. 30, 2016), https://perma.cc/JZA9-2X5L. .

61 Sarah Frier \& Matt Townsend, FTC to Crack Down on Paid Celebrity Posts That Aren't Clear Ads, BLOOMBERG (Aug. 5, 2016, 11:42 AM), https://perma.cc/AG7R-L22L.

62 Cohen, supra note 10

63 See Buzzfeed, supra note 58.

64 Toyota, The 14 Coolest Hybrid Animals, BuzzFEED (March 31, 2012, 6:36 PM), https:/perma.cc/6JLA-YQKH (last visited Nov 29, 2016).

65 Lucia Moses, Native ad grudge match: Wired vs. The New York Times, DiGIDAY (July 7, 2014), https://perma.cc/JS4P-4ZVT.

66 See The Viral Video Chart, ADVERTISINGAGE, https:/perma.cc/RP5H-7EES. 


\section{III.PAST RESEARCH, INDUSTRY GUIDELINES, AND THE LAW OF NATIVE ADVERTISING}

\section{A. Past Research}

The empirical literature on native advertising is modest - only two studies have been published in academic journals. Contently used an online survey see whether respondents were able to determine whether six native ads were unpaid content ("an article") or paid content ("an advertisement.") 67 For four of the six tested examples, a majority believed the native ads were unpaid content. The percentage of respondents that believed the examples were paid content ranged from $20 \%$ to $71 \%$. Respondents also varied in their ability to identify which advertiser was responsible for the paid content - ranging from $63 \%$ to $88 \%$, depending on the native ad.

Another study evaluated the reaction of respondents to native ads presented in the context of business news, entertainment news, and general news. ${ }^{68}$ They found that $82 \%-85 \%$ of respondents thought the content was clearly paid for by a brand/advertiser when presented along with business and entertainment news, but only $41 \%$ believed that when it was presented with general news.

Another study evaluated the impact of the position of the native ad on the search results page ("SRP") and labeling on 242 respondents' ability to recognize that it was paid content. ${ }^{69}$ They find that middle and bottom positioning on the SRP, as well as labeling that uses the words "advertising" and "sponsored" increased the likelihood that the content would be identified as advertising. They also note that "ad recognition generally led to more negative evaluations."

Another study presented 598 respondents with a blog that contained an imbedded labeled advertorial. ${ }^{70}$ They find a significant minority (27\%) of respondents believed the advertorial was written by a reporter or editor. The study did not explicitly ask whether the content in question was an ad or unpaid editorial/news content - and the

67 Joe Lazauskas, Study: Article or Ad? When It Comes to Native, No One Knows, CONTENTLY (Sep. 8, 2015), https://perma.cc/MA56-B8PV.

68 Edelman, Berland \& IAB, Getting In-Feed Sponsored Content Right: The Consumer View, InTERnET AdVERTISING BUREAU (2015), https://perma.cc/G6EM-E6D9

69 Bartosz W. Wojdynski and Nathaniel J. Evans, Going Native: Effects of Disclosure Position and Language on the Recognition and Evaluation of Online Native Advertising, 45 J. ADVERT. 157 (2016).

70 Chris Jay Hoofnagle \& Eduard Meleshinsky, Native Advertising and Endorsement: Schema, Source-Based Misleadingness, and Omission of Material Facts, TECHNOLOGY SCIENCE (Dec. 15, 2015), https://perma.cc/F4BN-FQ8T. 
emergence of in-house units devoted to the creation of native advertising complicates the interpretation of the findings. In addition, the survey population was non-random (drawn from four behavioral advertising email lists), and the response rate was exceptionally low. ${ }^{71}$ That said, these findings are consistent with the other literature, indicating a significant degree of consumer confusion.

Finally, an earlier generation of studies involving print and televised ads reached similar conclusions. For example, Kim, Pasadeos and Barban found that "the advertorial format fools readers into greater involvement with the advertising message and ... the presence of advertorial labels may not be particularly effective in alerting consumers to the true nature of the message." 72

\section{B. Industry Guidelines}

The IAB UK published guidelines in $2015 .^{73}$ These guidelines required the use of "reasonably visible" labels and "prominently visible visual cues" so that consumers would immediately recognize they are looking at "marketing content that has been compiled by a third party in a native ad format and is not editorially independent." 74 For labeling, the IAB UK suggested "paid promotion" or "brought to you by." For visual cues, the IAB UK suggested the use of brand logos, varying fonts, and/or shading that would clearly differentiate the ad from the surrounding editorial content. However, the IAB has no enforcement authority, and brand owners, publishers, and platforms suffer no adverse consequences if they do not adhere to these guidelines.

The National Advertising Division ("NAD") reviews ads, and publishes decisions that clarify whether particular ads are fraudulent or deceptive. ${ }^{75}$ In the past few years, the NAD has issued opinions

71 Emails were sent to 119,216 individuals. Although $30 \%-40 \%$ of the emails were undeliverable, that still means the response rate was at most $0.77 \%$. This is an exceptionally low response rate.

72 Bong-Hyun Kim, Yorgo Pasadeos \& Arnold Barban, On the Deceptive Effectiveness of Labeled and Unlabeled Advertorial Formats, 4 MASs COMMUNICATION \& SOCIETY 265 (2001). See also Micael Dahlén \& Mats Edenius, When is Advertising Advertising? Comparing Responses to Non-Traditional and Traditional Advertising Media, 29 J. CurR. Issues Res. AdverTising 33 (2007); Jacob Jacoby \& Wayne D. Hoyer, The Comprehension/Miscomprehension of Print Communication: Selected Findings, $15 \mathrm{~J}$. Consumer REs. 434 (1989); Jacob Jacoby \& Wayne Hoyer, Viewer miscomprehension of televised communication: Selected findings, 46 J. MARKETING 12 (1982).

73 IAB launches guidelines to provide greater transparency in 'native' digital advertising, INTERNET ADVERTISING BUREAU UK (Sept. 2, 2015), https://perma.cc/9D54-YLDM .

74 Id.

75 National Advertising Division, COUnCIL OF BETTER Business Bureaus, 
regarding several native advertising campaigns. Although NAD has no regulatory authority, one opinion prompted a publishing intermediary (Taboola) to change the font size, color, boldness, and placement of its labeling. ${ }^{76}$

\section{The Law of Native Advertising}

Native advertising is subject to the same legal constraints as "regular" advertising. Section 5 of the Federal Trade Commission Act vests the FTC with the responsibility to regulate misleading or deceptive advertising practices. The relevant provision was added to the FTC Act by the Wheeler-Lea Act, which declared "unfair or deceptive acts or practices" unlawful. 77 The Wheeler-Lea Act did not define "deceptive acts or practices" in concrete terms, leaving it to the FTC to sort out that issue by bringing enforcement actions. In 1984, the FTC issued a policy statement that spells out the necessary elements that must be proven to establish a claim of deception:

Certain elements undergird all deception cases. First, there must be a representation, omission or practice that is likely to mislead the consumer. Practices that have been found misleading or deceptive in specific cases include false oral or written representations, misleading price claims, sales of hazardous or systematically defective products or services without adequate disclosures, failure to disclose information regarding pyramid sales, use of bait and switch techniques, failure to perform promised services, and failure to meet warranty obligations.

Second, we examine the practice from the perspective of a consumer acting reasonably in the circumstances. If the representation or practice affects or is directed primarily to a particular group, the Commission examines reasonableness from the perspective of that group.

Third, the representation, omission, or practice must be a "material" one. The basic question is whether the act or practice is likely to affect the consumer's conduct or decision with regard to a product or service. If so, the practice is material, and consumer injury is likely, because consumers are likely to have chosen differently but for the deception. In many instances, materiality, and

https:/perma.cc/43CV-3M9A.

76 Ever Blurred Lines, supra note 23, at 1205-1207.

77 Wheeler-Lea Act, ch. 49, 52 Stat. 111 (1938) (codified at 15 US.C. $\S 45$ (a)). 
hence injury, can be presumed from the nature of the practice. In other instances, evidence of materiality may be necessary.

Thus, the Commission will find deception if there is a representation, omission or practice that is likely to mislead the consumer acting reasonably in the circumstances, to the consumer's detriment. ${ }^{78}$

Consistent with the framework in this policy statement, the FTC has handled multiple cases of deception where advertising is presented as unpaid news or editorial content:

Over the years, the Commission has challenged as deceptive a wide variety of advertising and other commercial message formats, including "advertorials" that appeared as news stories or feature articles, directmail ads disguised as book reviews, infomercials presented as regular television or radio programming, inperson sales practices that misled consumers as to their true nature and purpose, mortgage relief ads designed to look like solicitations from a government agency, emails with deceptive headers that appeared to originate from a consumer's bank or mortgage company, and paid endorsements offered as the independent opinions of impartial consumers or experts. ${ }^{79}$

Despite this extensive enforcement history, the FTC did not specifically address the issue of native advertising until December, 2015, when it issued an enforcement policy statement on deceptively formatted advertisements and a guide for businesses on native advertising: ${ }^{80}$ The enforcement policy statement makes it clear that the FTC believes that "advertising and promotional messages that are not identifiable as advertising to consumers are deceptive if they mislead consumers into believing they are independent, impartial, or not from the sponsoring advertiser itself." 81 Native advertising is particularly prone to this difficulty, because publishers/platforms are offering "advertisers formats and techniques that are closely integrated with and less distinguishable from regular content so that they can capture the attention and clicks of ad-avoiding consumers." ${ }^{2}$ Stated differently,

Fed. Trade Comm'n, FTC Policy Statement on Deception (Oct. 14, 1983) (appended to Cliffdale Associates, Inc., 103 F.T.C. 110, 174 (1984)), https://perma.cc/6SZA-SDJJ.

79 Fed. Trade Comm'n, Enforcement Policy Statement, supra note 26, at 1-2

80 Id. at 2

81 Id. at 1

82 Id. at 2 
the FTC is (understandably) concerned that native advertising is being used because it encourages consumers to "give greater credence to advertising claims or to interact with advertising content with which they otherwise would not have interacted." 83

\section{OUR METHODOLOGY AND FINDINGS}

\section{A. Methodology}

All respondents saw 18 images (in random order) and then two videos. The 18 images included 8 native ads, 1 modified native ad, 3 "regular" ads, and 6 examples of unpaid content. In total, we tested 16 native ads, 5 "regular ads," 8 examples of news and editorial content, and 3 video commercials. Native ads were selected from eight different platforms: The Allantic, BuzzFeed, Facebook, Forbes, Gawker, Mashable, The New York Times, The Onion, and Vanity Fair. "Regular" ads were selected from four platforms: The Atlantic, Facebook, Forbes, and Vanity Fair. Unpaid content was selected from seven platforms: The Atlantic, BuzzFeed, Facebook, Forbes, The New York Times, The Onion, and Vanity Fair. The three video ads were for Little Caesars, Nike, and Papa Johns. Copies of all the images and videos we tested are available on request.

We fielded the online survey in January, 2015. Respondents were procured by a well-known survey firm (SSI), and had to be at least 18. Details on the demographics of survey respondents are included in the appendix.

\section{B. Overview of Findings}

Table 1 provides summary survey completion statistics. To ensure respondents were not simply clicking through, we excluded those who completed the survey in less than five minutes, or incorrectly answered our "paying attention" question ("what is 5+7").

Id. at 10 (citation omitted) 
Table 1: Survey Completion Statistics

\begin{tabular}{|l|c|c|}
\hline & No. & Share \\
\hline Initiated Survey & 1,228 & $100 \%$ \\
\hline Completed Survey & 1,019 & $83 \%$ \\
\hline Completed Survey and "Paid Attention" & 914 & $74 \%$ \\
\hline $\begin{array}{l}\text { Completed Survey, and "Paid Attention," } \\
\text { and took } \geq 5 \text { minutes }\end{array}$ & 896 & $73 \%$ \\
\hline
\end{tabular}

"Completed survey" means that respondent did not terminate the survey by prematurely logging out or closing the browser window, and accordingly answered each question. "Paid Attention" = answered our attention question correctly ("what is $5+7$ ").

Figure 1 summarizes our findings as to whether respondents can identify ads when they see them - and whether there is any difference between their ability to recognize native ads v. "regular" ads.

\section{Figure 1: Do Consumers Recognize That Native Ads and Regular Ads Are Paid Content?}

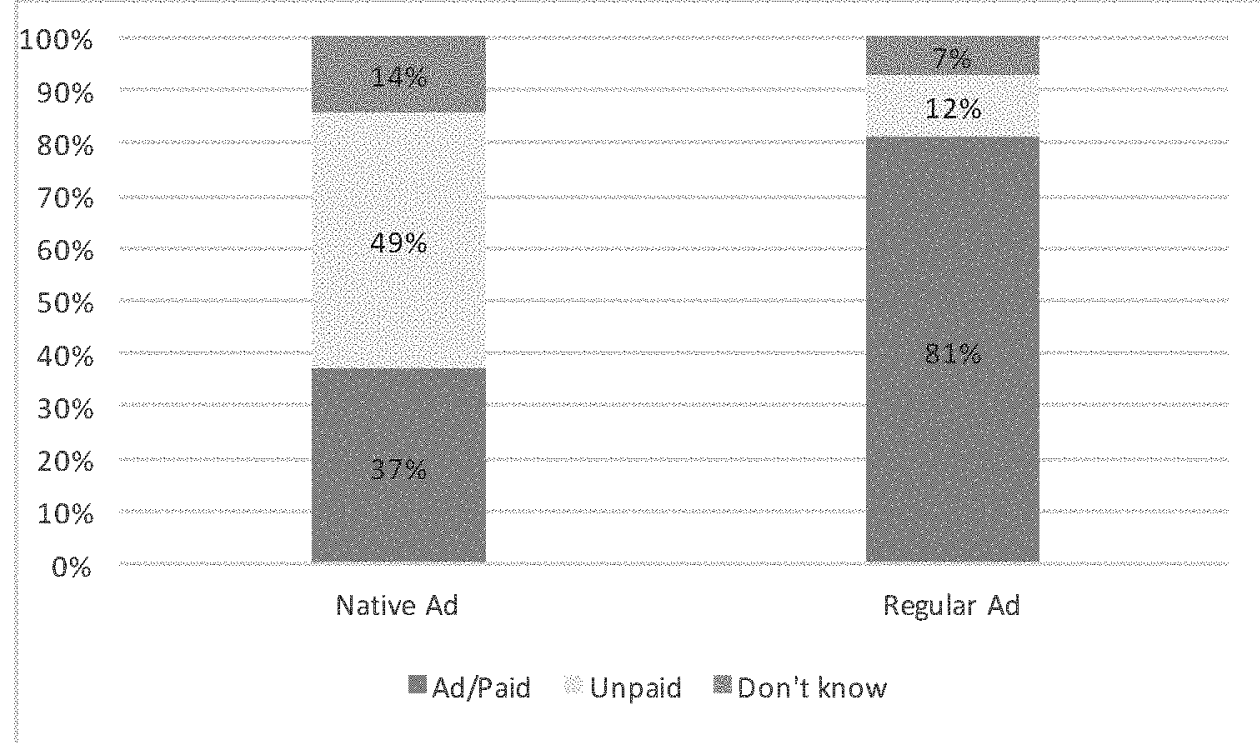

Share of respondents identifying native ads and regular ads as ads/paid content; unpaid content; and don't know. Results are averaged across sixteen different native ads, and five regular ads. Don't know = don't know/can't tell/not sure.

Figure 1 shows that only $37 \%$ of respondents knew that the tested native ads were paid content - far less than the $81 \%$ of respondents who knew that "regular" ads were paid content (t-stat=42.36; $\mathrm{p}<0.001)$. A substantial majority of those who didn't know that native ads were paid content believed that they were unpaid content, as opposed to "don't know." 
Figure 1 presents combined results for all sixteen of the native ads we tested. How much variation do we observe when we disaggregate these findings and look at each individual native ad? Table 2 provides the answer, sorted by the share of respondents that got the "right answer" - i.e., correctly recognized that the tested native ad was advertising/paid content.

Table 2: Do Respondents Recognize that Native Ads Are Paid Content?

\begin{tabular}{|l|l|l|c|c|c|}
\hline & \multicolumn{4}{|c|}{ Tested Content } & \multicolumn{2}{c|}{ Respondents thought content was } \\
\hline \multirow{2}{*}{ No. } & Platform & Advertiser & $\begin{array}{c}\text { Ad/paid } \\
\text { content }\end{array}$ & $\begin{array}{c}\text { Unpaid } \\
\text { content }\end{array}$ & $\begin{array}{c}\text { Don't } \\
\text { know }\end{array}$ \\
\hline 1. & Facebook & Jaspers & $\mathbf{7 2 \%}$ & $21 \%$ & $7 \%$ \\
\hline 2. & Mashable & Pay Pal & $\mathbf{4 8 \%}$ & $41 \%$ & $11 \%$ \\
\hline 3. & Facebook & Wiseguy & $\mathbf{4 7 \%}$ & $40 \%$ & $14 \%$ \\
\hline 4. & Gawker & TBS & $\mathbf{4 0} \%$ & $42 \%$ & $18 \%$ \\
\hline 5. & Forbes & Fidelity & $\mathbf{3 8 \%}$ & $50 \%$ & $12 \%$ \\
\hline 6. & N.Y. Times & Dell & $\mathbf{3 6 \%}$ & $49 \%$ & $15 \%$ \\
\hline 7. & Vanity Fair & Hennessy & $\mathbf{3 6 \%}$ & $46 \%$ & $18 \%$ \\
\hline 8. & Buzzfeed & Amtrak & $\mathbf{3 5 \%}$ & $51 \%$ & $14 \%$ \\
\hline 9 & Fastcompany & UPS & $\mathbf{3 3 \%}$ & $42 \%$ & $25 \%$ \\
\hline 10. & Buzzfeed & Toyota & $\mathbf{3 2 \%}$ & $57 \%$ & $11 \%$ \\
\hline 11. & N.Y. Times & Netflix & $\mathbf{3 0 \%}$ & $56 \%$ & $14 \%$ \\
\hline 12. & Onion & H.R. Block & $\mathbf{2 9 \%}$ & $56 \%$ & $15 \%$ \\
\hline 13. & Atlantic & Scientology & $\mathbf{2 8 \%}$ & $56 \%$ & $16 \%$ \\
\hline 14. & Buzzfeed & Mini & $\mathbf{2 6 \%}$ & $61 \%$ & $13 \%$ \\
\hline 15. & Forbes & SAP & $\mathbf{2 1 \%}$ & $67 \%$ & $13 \%$ \\
\hline 16. & Onion & Burger & $\mathbf{2 1 \%}$ & $62 \%$ & $17 \%$ \\
\hline \hline & & King & $\mathbf{3 7 \%}$ & $49 \%$ & $14 \%$ \\
\hline All Native Advertising & & & \\
\hline
\end{tabular}

Share of respondents identifying particular native ad as an ad/paid content; unpaid content; and don't know. Bold indicates the correct answer. Don't know $=$ don't know/can't tell/not sure.

As Table 2 indicates, there is considerable variation among the tested native ads - although with one exception, all of the tested native ads had recognition rates (i.e., the share of respondents that correctly identified the native ad as an ad/paid content) below 50\%. The native ad with the highest recognition rate was Jaspers grocery store, which 
appeared on Facebook (72\%). The native ad with the worst recognition rate was Burger King, which appeared on The Onion website (21\%).

Do we find similar variation when we disaggregate the results for "regular" advertising? And, how good are respondents at correctly identifying unpaid news and editorial content? Table 3 provides the answers - again sorted by the share of respondents that got the "right" answer.

Table 3: Do Respondents Recognize That Regular Ads Are Paid Content, and News Articles and Editorials Are Unpaid Content?

\begin{tabular}{|c|c|c|c|c|c|}
\hline \multicolumn{6}{|c|}{ Regular Ads } \\
\hline No. & Venue & Advertiser & $\begin{array}{l}\text { Ad/paid } \\
\text { content }\end{array}$ & $\begin{array}{l}\text { Unpaid } \\
\text { content }\end{array}$ & $\begin{array}{l}\text { Don't } \\
\text { know }\end{array}$ \\
\hline 1. & Forbes & IBM \#2 & $85 \%$ & $8 \%$ & $7 \%$ \\
\hline 2. & Forbes & IBM \#1 & $84 \%$ & $9 \%$ & $7 \%$ \\
\hline 3. & Vanity Fair & Clinique & $84 \%$ & $9 \%$ & $8 \%$ \\
\hline 4. & Facebook & Dresslily & $81 \%$ & $13 \%$ & $6 \%$ \\
\hline 5. & Atlantic & Chevron & $\mathbf{7 9} \%$ & $13 \%$ & $8 \%$ \\
\hline \multicolumn{3}{|l|}{ All } & $81 \%$ & $12 \%$ & $7 \%$ \\
\hline \multicolumn{6}{|c|}{ News Articles and Editorials } \\
\hline 1. & N.Y. Times & Prison & $11 \%$ & $78 \%$ & $11 \%$ \\
\hline 2. & Atlantic & Police Photo & $12 \%$ & $77 \%$ & $11 \%$ \\
\hline 3. & Onion & Time Together & $16 \%$ & $73 \%$ & $11 \%$ \\
\hline 4. & Forbes & Mistake Airfare & $21 \%$ & $65 \%$ & $14 \%$ \\
\hline 5. & Forbes & Dementia & $24 \%$ & $64 \%$ & $13 \%$ \\
\hline 6. & Buzzfeed & Dinners & $25 \%$ & $61 \%$ & $14 \%$ \\
\hline 7. & Vanity Fair & Making Billions & $31 \%$ & $\mathbf{5 2} \%$ & $17 \%$ \\
\hline 8. & Facebook & Comcast Sportsnet & $38 \%$ & $46 \%$ & $16 \%$ \\
\hline \multicolumn{3}{|l|}{ All } & $22 \%$ & $65 \%$ & $13 \%$ \\
\hline
\end{tabular}

Share of respondents identifying regular ads and news articles/editorials as an ad/paid content; unpaid content; and don't know. Bold indicates the correct answer. Don't know $=$ don't know/can't tell/not sure.

Table 3 shows that for regular ads, there is much less variance by advertiser and platform than for native ads. On average $81 \%$ of respondents correctly determined that regular ads were paid content, with the response for individual ads falling into a narrow range (79\%$85 \%)$.

Table 3 also shows that just under two-thirds of respondents (65\%) correctly determined the tested news articles and editorials were 
unpaid content, with less variation than native advertising, but more variation than regular advertising (range 46\%-78\%). On average, $22 \%$ of respondents thought the unpaid news/editorial content was an ad/paid content. Of course, this "problem" does not raise the same legal issues as the reverse situation involving native ads and regular ads -but it provides a useful control for our other findings, and indicates there is a considerable degree of two-way blurring in this space. ${ }^{84}$

\section{Effectiveness of Labeling and Pop-Ups}

We now turn to the effectiveness of labeling and other strategies used to signal the presence of paid content. We begin by noting the diversity of labels used by different platforms to identify native ads, including "sponsored content," "paid posts," "partner content," "promoted by," and "brand publisher." Some platforms also use different labels to identify native advertising and "regular" ads. To what extent do any of these labels actually signal to readers that the content in question is a paid ad?

We showed respondents a list of 13 labels, and asked them whether each label, viewed in isolation, indicated the associated content was an ad/paid content; unpaid news/editorial content; or don't know/can't tell/not sure. Table 4 presents the results of this evaluation, sorted by the percentage of respondents that thought the label indicated an ad/paid content. 
Table 4: Consumer Perceptions of Native Advertising Labels

\begin{tabular}{|l|c|c|c|}
\hline Label & $\begin{array}{c}\text { Ad/paid } \\
\text { content }\end{array}$ & $\begin{array}{c}\text { Unpaid } \\
\text { content }\end{array}$ & $\begin{array}{c}\text { Don't } \\
\text { know }\end{array}$ \\
\hline Paid Ad & $89 \%$ & $4 \%$ & $6 \%$ \\
\hline Paid Content & $87 \%$ & $5 \%$ & $8 \%$ \\
\hline $\begin{array}{l}\text { This content was } \\
\text { paid for by }\end{array}$ & $86 \%$ & $6 \%$ & $8 \%$ \\
\hline Paid Post & $83 \%$ & $7 \%$ & $10 \%$ \\
\hline Ad & $81 \%$ & $7 \%$ & $12 \%$ \\
\hline Sponsored & $79 \%$ & $11 \%$ & $10 \%$ \\
\hline Sponsored Content & $76 \%$ & $12 \%$ & $12 \%$ \\
\hline Sponsored Post & $76 \%$ & $13 \%$ & $11 \%$ \\
\hline Brand Voice & $64 \%$ & $16 \%$ & $20 \%$ \\
\hline Brand Publisher & $61 \%$ & $19 \%$ & $20 \%$ \\
\hline Presented By & $60 \%$ & $20 \%$ & $20 \%$ \\
\hline Partnered Content & $57 \%$ & $19 \%$ & $24 \%$ \\
\hline Partner & $57 \%$ & $17 \%$ & $26 \%$ \\
\hline Written By & $23 \%$ & $52 \%$ & $25 \%$ \\
\hline
\end{tabular}

Share of Respondents that believed identified labels were associated with (1) ad/paid content, (2) unpaid content, and (3) don't know. Labels were presented without any associated content. Don't know $=$ don't know/can't tell/not sure.

Unsurprisingly, the more overt the label, the higher the percentage of respondents that expected it to be associated with paid content. Labels that used the word "paid" were believed to be associated with paid content by $83 \%-89 \%$ of respondents. ${ }^{85}$ Labels using the word "sponsored" did somewhat less well, with $76 \%-79 \%$ of respondents believing such labels were associated with paid content. Finally, several of the labels that are widely used to indicate native advertising (e.g., Brand Voice, Brand Publisher, Presented By, Partnered Content, and Partner) were believed to be associated with paid content by only $57 \%-64 \%$ of respondents.

In all fairness, a label that uses the word "paid" seems quite unambiguous. So, it is somewhat disconcerting to discover that $4 \%-7 \%$ of respondents thought that label was associated with unpaid content, and 6\%-10\% didn't know. See Table 4, supra. These findings hint at some of the difficulties associated with disclosure/labeling strategies. See also infra note 104 , and accompanying text. 
Of course, labels are not the only way to signal the presence of paid content. Forbes' native advertising is labeled "Brand Voice" - a label that scores poorly in Table 4 - but the label has a link to an associated pop-up that provides additional information. The pop-up language reads as follows:

BrandVoice ${ }^{\mathrm{TM}}$ allows marketers to connect directly with our audience by enabling them to create content - and participate in the conversation - on our digital publishing platform. Each BrandVoice $^{\mathrm{TM}}$ is produced by the marketer.

Does this pop-up language effectively signal to readers that the associated content is paid advertising? We presented respondents with this pop-up text, and then asked them whether they believed the associated content was paid or unpaid. We had previously asked respondents the same question about the label "Brand Voice" before showing them the pop-up associated with that label; this earlier inquiry serves as our control for the effect of the pop-up language. Figure 2 presents the results.

Figure 2: Impact of Reading Pop-Up Text

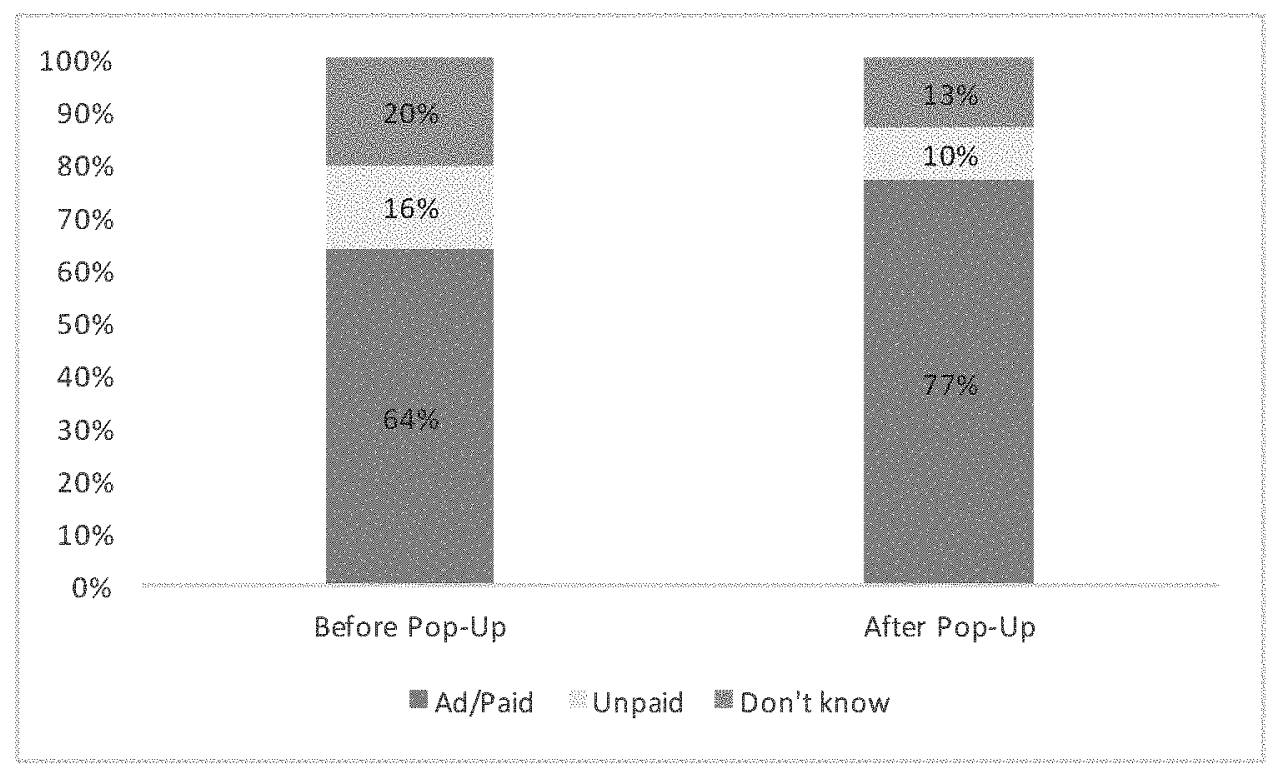

Share of respondents identifying content associated with Brand Voice as an ad/paid content; unpaid content; and don't know, before and after viewing pop-up text. Don't know $=$ don't know/can't tell/not sure.

Figure 2 shows that reading the pop-up text resulted in an increase in the share of respondents that correctly recognized the 
associated content was an ad from $64 \%$ to $77 \%(\mathrm{t}$-stat $=6.86 ; \mathrm{p}<0.001)$. However, it is important to note that in the results reported in Table 4 and Figure 2, we are testing labels in isolation. When we presented respondents with actual Brand Voice content, as Table 2 reflects, many fewer respondents (21\% for Forbes-SAP and 38\% for Forbes-Fidelity) correctly identified the native ads as ads/paid content.

We also asked respondents whether the content associated with the pop-up represented the views of the website, the brand owner, or both. In unreported analysis, we find that $48 \%$ of respondents thought the content represented the views of the brand owner, compared to $21 \%$ who thought it was the view of the website; $20 \%$ who thought it represented the views of both the website and the brand owner, and $12 \%$ who didn't know.

We extended our analysis of these issues by modifying the labeling on two native ads. Half of the respondents saw a control version of a native ad - and the other half saw a modified version, which made it clear that the associated content was paid. More specifically, for the Fidelity native ad that ran in Forbes, we inserted a grey horizontal bar just above the article text, that was clearly labeled "Paid Ad." For the Hennessey native ad that ran in Vanity Fair, we replaced the small label above the headline that said "Sponsor Content" with a yellow horizontal bar that was clearly labeled "Paid Ad" in large text. All respondents saw an unmodified version of one native ad (i.e., the control), and a modified version of a different native ad.

Figure 3 presents the results averaged across both modified native ads. The results for each modified native ad appear in the table immediately below Figure 3 . 
Figure 3: Impact of Modifying Labeling of Native Ads

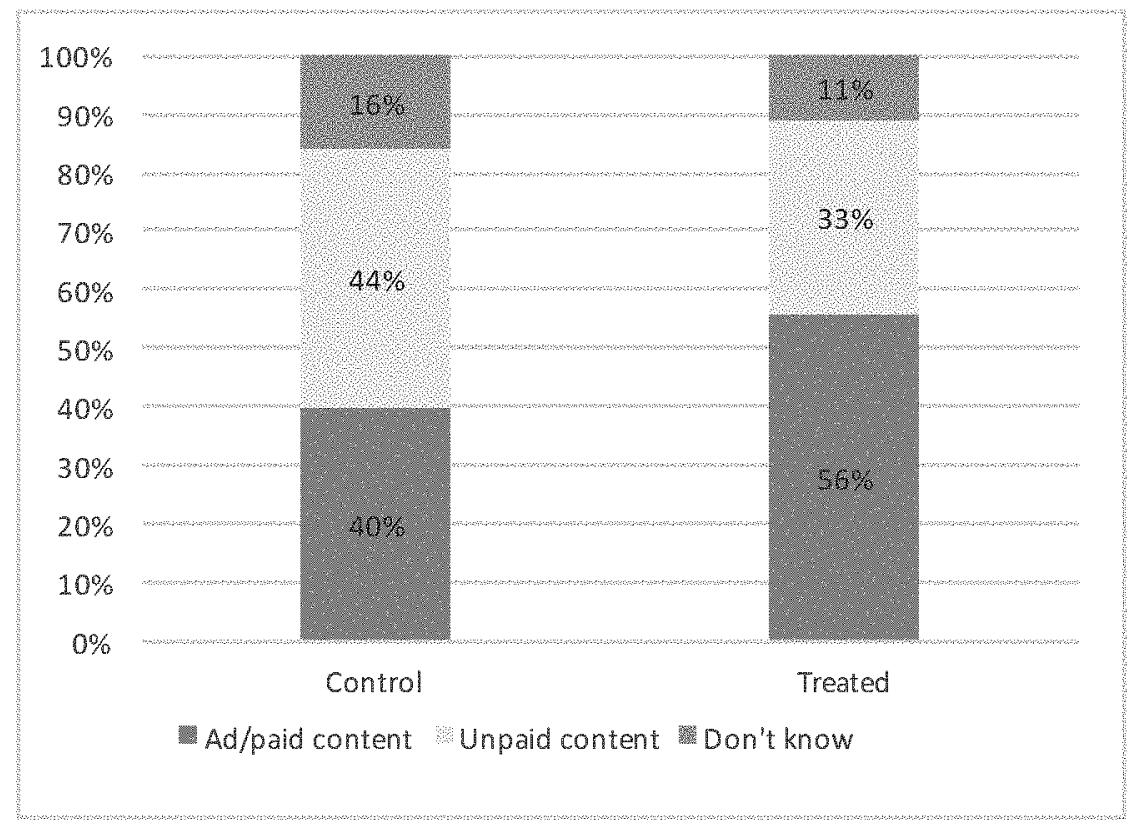

\begin{tabular}{|l|c|c||c|c|}
\hline Ad & \multicolumn{2}{|c||}{ Fidelity } & \multicolumn{2}{c|}{ Hennessey } \\
\hline Platform & \multicolumn{2}{|c|}{ Forbes } & \multicolumn{2}{c|}{ Vanity Fair } \\
\hline Modified? & Control & Treated & Control & Treated \\
\hline Content Is & & & & \\
\hline $\begin{array}{l}\text { Ad/paid } \\
\text { content }\end{array}$ & $44 \%$ & $57 \%$ & $36 \%$ & $54 \%$ \\
\hline $\begin{array}{l}\text { Unpaid } \\
\text { content }\end{array}$ & $42 \%$ & $33 \%$ & $46 \%$ & $33 \%$ \\
\hline $\begin{array}{l}\text { Don't } \\
\text { know }\end{array}$ & $14 \%$ & $10 \%$ & $18 \%$ & $12 \%$ \\
\hline
\end{tabular}

Share of respondents identifying two native ads as ads/paid content; unpaid content; and don't know, before (control) and after (treated) modifying labeling. Figure presents average results for both native ads; table provided breakdown for each ad. Don't know $=$ don't know/can't tell/not sure.

Figure 3 shows that relatively modest label changes can materially increase the share of respondents that realize the associated content is paid advertising - in this instance from $40 \%$ to $56 \%$ for the two native ads we tested. (t-stat $=7.31 ; \mathrm{p}<0.001)$. Of course, even with our modified labels, fully $33 \%$ of respondents believed the tested native ads were unpaid content, and 11\% didn't know. 
We also examined respondents' labeling preferences for identifying paid content, by asking them to rank order 11 different labels. ${ }^{86}$ Table 5 presents the results, sorted based on labeling preference, with a lower mean score indicating the label was preferred by more respondents.

Table 5: Consumer Labeling Preferences to Signal Paid Content

\begin{tabular}{|l|l|c|}
\hline Rank Order & Label & Mean Score \\
\hline 1 & Paid Ad & 4.15 \\
\hline 2 & This content was paid for by & 4.46 \\
\hline 3 & Paid Content & 4.61 \\
\hline 4 & Ad & 5.36 \\
\hline 5 & Sponsored & 5.45 \\
\hline 6 & Sponsored Content & 5.80 \\
\hline 7 & Presented By & 6.28 \\
\hline 8 & Partner Content & 7.36 \\
\hline 9 & Brand Publisher & 7.45 \\
\hline 10 & Partner & 7.52 \\
\hline 11 & Brand Voice & 7.57 \\
\hline
\end{tabular}

Mean ranking of labels, based on rank ordering from 1-11. Lower mean score indicates a higher (i.e., more popular) ranking

As Table 5 indicates, labels that use the word "ad" or "paid" are preferred over more ambiguous labels. Several labels that are widely used rank at the bottom of Table 5 .

We also tested three video commercials. The first commercial ("Big Game") was a "regular" ad for Little Caesars. ${ }^{87}$ Respondents were told it aired on the NBA Network. The second commercial "Choose Your Winter") was also a regular ad, but it only mentioned the brand that was being advertised (Nike) at the very end of the ad - and did so only by showing the logo. 88 The ad featured hockey, and respondents were told it was aired on the NHL Network. The third ("Thursday Night Football"), used the NFL Network set and featured Rich Eisen interacting with Papa John. ${ }^{89}$ Respondents were told this commercial aired on the NFL Network.

86 More specifically, the survey stated: "we are trying to identify a single label to use to identify all paid content on websites. Please rank these labels in order of preference."

87 Little Caesar's Pizza, Big Game Headquarters Commercial, YouTuBe (Nov 29, 2016), https://perma.cc/4H89-PWXT.

88 AS G, Choose Your Winter, YouTuBE (Nov 29, 2016), https://perma.ce/V2UF-RZQ9.

89 Papa John's, Papa John's and Friday Night Football, YouTuBE (Nov 29,2016), https:/perma.cc/X394-GLZ7. 
The Little Caesars ad was the most overtly commercial. The Nike commercial, like many of their other ads, did not highlight the brand or associated products. The Papa John's commercial felt the most like native advertising - albeit in video form. Respondents saw the Papa Johns ad, and either the Little Caesars or Nike ad. Compared to print and online advertising, respondents were far more likely to identify all three commercials as paid content. $95 \%$ of respondents thought the Papa Johns commercial was an ad, compared to $90 \%$ for Little Caesars, and $85 \%$ for Nike.

We also asked respondents whether the video represented the views of the brand owner; the network on which the commercial was broadcast; both the brand owner and the network; or don't know. Figure 4 presents the results.

\section{Figure 4: Whose Views Do the Commercial Represent?}

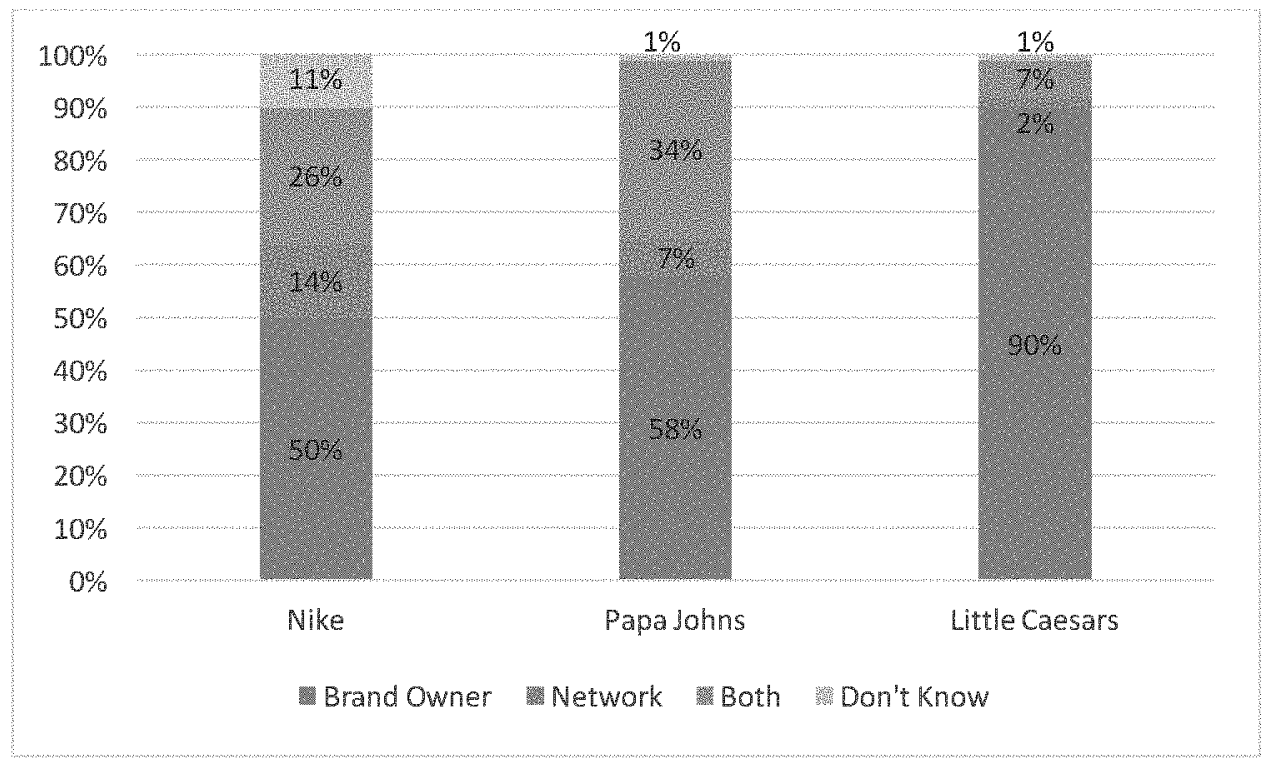

An overwhelming majority of respondents thought that the Little Caesars commercial represented the views of the brand owner alone $(90 \%)$. Far lower percentages thought that about the Nike $(50 \%)$ and Papa Johns (58\%) commercials. Perhaps the most intriguing finding was that $26 \%$ of respondents thought the Nike commercial represented the views of both Nike and the NHL Network, and 34\% of respondents thought the Papa Johns commercial represented the views of Papa Johns and the NFL Network. More modest percentages thought these commercials represented the views of the NHL Network (14\%) and the NFL Network (7\%) alone. 


\section{Attitudes Regarding Advertising}

At the conclusion of the survey, we asked the participants about their attitudes regarding regular and native advertising using a 5-point Likert scale. We present the results in Table 6.

\section{Table 6: Attitudes Regarding Advertising and Native Advertising}

\begin{tabular}{|c|c|c|c|c|c|c|}
\hline $\begin{array}{l}\text { Degree of } \\
\text { Preference }\end{array}$ & $\begin{array}{l}\text { Strongly } \\
\text { Disagree } \\
\end{array}$ & Disagree & Neutral & Agree & $\begin{array}{c}\text { Strongly } \\
\text { Agree }\end{array}$ & 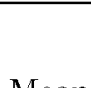 \\
\hline Scaled Score & 1 & 2 & 3 & 4 & 5 & Score \\
\hline $\begin{array}{l}\text { I am skeptical of } \\
\text { Ads/paid content }\end{array}$ & $2 \%$ & $7 \%$ & $25 \%$ & $44 \%$ & $22 \%$ & 3.8 \\
\hline $\begin{array}{l}\text { I can easily } \\
\text { recognize the } \\
\text { difference between } \\
\text { Ads/Paid content } \\
\text { and unpaid } \\
\text { content }\end{array}$ & $3 \%$ & $7 \%$ & $23 \%$ & $45 \%$ & $21 \%$ & 3.75 \\
\hline $\begin{array}{l}\text { Businesses } \\
\text { mislead/deceive } \\
\text { the public through } \\
\text { Ads/paid content }\end{array}$ & $2 \%$ & $8 \%$ & $34 \%$ & $39 \%$ & $17 \%$ & 3.6 \\
\hline $\begin{array}{l}\text { It is important for } \\
\text { me to know } \\
\text { whether content is } \\
\text { paid or unpaid }\end{array}$ & $3 \%$ & $10 \%$ & $28 \%$ & $36 \%$ & $22 \%$ & 3.6 \\
\hline $\begin{array}{l}\text { I trust unpaid } \\
\text { content more than } \\
\text { Ads/paid content }\end{array}$ & $4 \%$ & $6 \%$ & $38 \%$ & $36 \%$ & $15 \%$ & 3.5 \\
\hline $\begin{array}{l}\text { I rely on unpaid } \\
\text { content more than } \\
\text { Ads/paid content }\end{array}$ & $5 \%$ & $9 \%$ & $38 \%$ & $9 \%$ & $18 \%$ & 3.5 \\
\hline $\begin{array}{l}\text { I can distinguish } \\
\text { between native } \\
\text { advertising and } \\
\text { unpaid content }\end{array}$ & $5 \%$ & $14 \%$ & $38 \%$ & $34 \%$ & $9 \%$ & 3.3 \\
\hline $\begin{array}{l}\text { I trust native } \\
\text { advertising more } \\
\text { than regular } \\
\text { Ads/paid content }\end{array}$ & $11 \%$ & $20 \%$ & $43 \%$ & $19 \%$ & $7 \%$ & 2.9 \\
\hline
\end{tabular}

Table 6 indicates that many respondents are skeptical of ads/paid content, and trust and rely on them less than unpaid content; think that it is important that they know whether content is paid or unpaid; and believe that businesses use ads/paid content to mislead the public. In the two questions that focused explicitly on native advertising, 43\% of respondents believe they are able to distinguish between native 
advertising and unpaid content (9\% strongly agree, and 34\% agree). Another 38\% don't have a strong opinion on the subject. However, Figure 1 and Table 2 show that respondents actually have considerable difficulty determining whether native advertising is paid content. And only $26 \%$ of respondents indicate that they trust native advertising more than regular advertising (7\% strongly agree, and 19\% agree).

The cluster of views documented in Table 6 , as well as in earlier research, helps explain the appeal of native advertising to brand owners. Native advertising is designed to merge seamlessly into the unpaid news and editorial content that appears on each platform meaning that it is much more likely to circumvent the skepticism and mistrust that would otherwise cause paid content to be ignored or discounted.

\section{E. Do Users Learn From Experience?}

At the beginning of the survey, we asked respondents whether they could easily recognize the difference between ads/paid content and unpaid content. Table 6 contains the responses to that question -- 21\% strongly agreed; $45 \%$ agreed; $23 \%$ neither agreed nor disagreed; and $10 \%$ disagreed or strongly disagreed. The scaled score for the response to this question was 3.75 - second highest for all of the questions in Table 6 .

At the end of the survey, we told each respondent how well they had done in identifying which content was paid and unpaid - expressed in terms of a percentage, ranging from $0 \%$ to $100 \%$. We treated "don't know/not sure/can't tell" as an incorrect answer. We then re-asked the same question in Table 6 - whether respondents could easily recognize the difference between ads/paid content and unpaid content. In unreported analysis, we found that the average overall response declined from 3.75 (per Table 6) to 3.31. The decline was comparable for those who got less than $50 \%$ correct (3.48 to 3.06 , or 0.42 decline) and those who got more than $75 \%$ correct ( 4.14 to 3.76 , or 0.38 decline). So, at least in the short-run, providing feedback on performance had an impact on users' self-reported confidence in their ability to recognize ads/paid content.

\section{F. Regression Analysis}

We also conducted OLS regression examining whether respondents' performance ability varied based on age; education; employment in advertising/marketing; and self-reported ability to easily 
differentiate ads/paid content from unpaid content. Table 7 presents the results of this analysis.

Table 7: Regression Results

\begin{tabular}{|c|c|c|c|c|c|c|}
\hline \multirow{2}{*}{\begin{tabular}{|l|}
$\begin{array}{l}\text { Dependent } \\
\text { Variable }\end{array}$ \\
Regression
\end{tabular}} & \multicolumn{2}{|c|}{$\%$ Correct (All) } & \multicolumn{2}{|c|}{$\%$ Correct (Paid) } & \multicolumn{2}{|c|}{$\%$ Correct (Native Only) } \\
\hline & (1) & (2) & (3) & (4) & (5) & (6) \\
\hline \multirow[t]{2}{*}{ Age } & $0.08 \div * *$ & $0.07 \div *$ & $0.13 \div * *$ & $0.13 * * * *$ & $0.23 \div * *$ & $0.23 * * *$ \\
\hline & $(2.21)$ & $(2.08)$ & $(3.02)$ & $(2.94)$ & $(4.24)$ & $(4.14)$ \\
\hline \multirow[t]{2}{*}{ Gender } & -0.05 & 0.28 & -0.88 & -0.65 & -1.28 & -1.03 \\
\hline & $(-0.05)$ & $(0.27)$ & $(-0.70)$ & $(-0.52)$ & $(-0.79)$ & $(-0.63)$ \\
\hline \multirow[t]{2}{*}{$\begin{array}{l}\text { Marketing or } \\
\text { Advertising } \\
\text { Experience }\end{array}$} & 0.21 & 0.32 & $6.64^{*}$ & $7.16^{*}$ & $17.61 * * *$ & $17.96 * * *$ \\
\hline & $(0.06)$ & $(0.10)$ & $(1.66)$ & $(1.78)$ & (3.39) & $(3.45)$ \\
\hline \multirow[t]{2}{*}{$\begin{array}{l}\text { Self-reported } \\
\text { Ability }\end{array}$} & $4.33^{* * *}$ & 4.17**** & $4.01 \div * *$ & $3.87 * * *$ & $4.80 * * *$ & $4.66^{* * *}$ \\
\hline & $(8.25)$ & $(7.92)$ & $(6.27)$ & $(6.02)$ & $(5.80)$ & $(5.60)$ \\
\hline \multirow[t]{2}{*}{ Constant } & 38.95 & 41.83 & 35.6 & 37.18 & 9.25 & 12.4 \\
\hline & $(13.67)$ & $(9.30)$ & $(10.26)$ & $(6.77)$ & $(2.06)$ & $(1.75)$ \\
\hline $\begin{array}{l}\text { Control for } \\
\text { Education? }\end{array}$ & No & Yes & No & Yes & No & Yes \\
\hline Observations & 896 & 896 & 896 & 896 & 896 & 896 \\
\hline $\begin{array}{l}\text { Adjusted R- } \\
\text { squared }\end{array}$ & 0.073 & 0.085 & 0.051 & 0.059 & 0.061 & 0.069 \\
\hline
\end{tabular}

OLS Regressions. Self-reported ability = response on a 1-5 scale of whether respondent can "easily recognize the difference between Ads/paid content and unpaid content," where $1=$ strongly disagree, and $5=$ strongly agree. $t$ statistics in parentheses. ${ }^{*}, * *$, *** indicate significance at the $10 \%, 5 \%$, and $1 \%$ levels. Significant results (at $5 \%$ or better) are in boldface.

As Table 7 indicates, age and self-reported ability are each associated with a higher percentage of correct responses. Gender was not significant in any of the regressions. Education dummies were not significant, and adding them had no effect on the coefficients for other independent variables. The coefficient on marketing/advertising experience was not significant for all tested examples (regressions (1)$(2))$, but was marginally significant $(p<0.1)$ for ads/paid content (regressions (3)-(4)), and statistically and economically significant for native ads alone (regressions (5)-(6)). 


\section{Discussion}

\section{A. The Logic of Native Advertising}

Native advertising represents a new (and potentially quite large) source of income for publishers and platforms - many of whom are facing increased competition and declining readership and revenues in a sector of the economy with few barriers to entry. For those worried about the economic sustainability of the news media in a world where anyone can start their own blog, native advertising has been a godsend. And, because alternatives are always "just a click away," publishers and platforms have an incentive to ensure that native advertising does not trigger mistrust, or disrupt the viewing experience.

Brand owners see native advertising as a way to educate consumers about problems or challenges - and the availability of their products and offerings to address those problems or challenges without triggering the usual skepticism associated with advertising. Many consumers conduct research and make purchasing decisions before they ever walk into a store, and online purchasing means that many consumers will never walk into a store. Native advertising presents a new way of reaching those consumers before they have made up their minds. Brand owners, publishers, and platforms that are too overt in their sales pitch, or come across as self-serving, irrelevant, or unhelpful will lose credibility with potential purchasers and readers/users - damaging their respective brands, and discouraging future purchases/readers. Thus, self-interest helps constrain the most egregious forms of misconduct.

Of course, even if these arguments represent compelling justifications for brand owners, publishers, and platforms to use native advertising, it does not follow that they are allowed to deceive consumers about whether content is paid. ${ }^{90}$ Deception is deception, no matter how worthy the justifications that are offered. We now turn to the evidence on that issue.

See, e.g., Thompson Med. Co., 791 F.2d 189, 195 (D.C. Cir. 1986) ("[A]lthough the effect of the order on Thompson's business may well be severe, we see no reason that Thompson should be able to make advertising claims if they are not true. The FTC has a mandate to assure that advertising is not false and misleading. Allowing firms to continue such advertising because to stop would hurt the firm's economic interests is obviously not part of the calculus of interests Congress intended the FTC to consider. Thompson has no right to stay in business if the only way it can do so is to engage in false and misleading advertising.") 


\section{B. Do Consumers Know That Native Advertising Is Paid?}

Figure 1 and Table 2 show that a clear majority of respondents do not understand that the tested examples of native advertising are paid content. As Table 3 shows, respondents did much better with "regular" advertising. We also find evidence of two-way blurring and confusion: as Table 3 shows, on average $22 \%$ of respondents believed that the news articles and editorials we tested were ads/paid content, and 13\% didn't know. As noted previously, this blurring does not raise the same legal issues as those involving native ads and regular ads, but it is indicative of a larger problem.

We tested sixteen examples of native advertising. For fifteen of the sixteen examples, fewer than $50 \%$ of respondents knew that native ads were paid content. Averaged across all sixteen examples, only $38 \%$ of respondents knew that native ads were paid content. The consistency of our findings is striking, given the diversity of labeling, layout, borders, platforms, and advertising.

Our findings should not come as a surprise; even the proponents of native advertising concede that it is intended to seamlessly blend in with news and editorial content. And, many media companies are setting up in-house units to handle native advertising - virtually ensuring that these ads will match the look and feel of their unpaid content.

What should be done about the fact that a substantial majority of respondents simply do not recognize that native advertising is, in fact, advertising? Of course, more research needs to be done, to confirm that our findings are representative. But, assuming our findings hold up, we should start by recognizing that self-regulation is not doing the job. We address the issue of remedies in more detail below.

\section{Trust and Integrity}

Advertising is supposed to be labeled clearly and conspicuously, so that readers/viewers can differentiate news and editorials from paid content. By mimicking the look and feel of unpaid content, native advertising adds noise to an already complex informational landscape.

We did not study the impact of native advertising on consumer trust - but decades of research has shown that many Americans dislike, distrust, and try to avoid advertising. ${ }^{91}$ In Table 6 , we report results 
consistent with that assessment. Native advertising is intended to circumvent these negative attitudes by simulating the look of unpaid content - i.e., by deception. Those who doubt this assessment might ponder Newsweek.com's online section on "Raising the Bar - Best Law Schools 2016." This publication was designed to "excite and motivate our readers to explore a career in the legal industry." 92 So far, so good except Newsweek offered any law school - no matter how awful their bar passage rate and employment statistics - the opportunity to be featured in the online section as one of the "Best Law Schools 2016" for the low, low cost of $\$ 6 \mathrm{k}-\$ 10 \mathrm{k}$. Newsweek featured five "Best Law Schools 2016" in a prominent sidebar: Western State College of Law; Nova Southeastern; University of Maryland School of Law; Appalachian School of Law; and New York Law School. The accompanying article mentioned all five of those schools, along with two others (Seattle University, and St. Thomas University). ${ }^{93}$

But for the payment of $\$ 6 \mathrm{k}-\$ 10 \mathrm{k}$, does anyone believe Newsweek would have identified these institutions as the "Best Law Schools 2016?"94 Given that fact, why should visitors trust anything on the Newsweek website?

People who find out they have been deceived are likely to lose trust in the deceivers. An uncontrolled study of native advertising found just that ${ }^{95}$ Unless additional steps are taken to address these

Regulation (AEI Press 1997). But see Eva van Reijmersdal, Peter Neijens and Edith Smit, Readers' Reactions to Mixtures of Advertising and Editorial Content in Magazines, 27 J. CurR. Issues Res. Advertising 39 (2005).

92 Joe Patrice, Schools Touting Appearance in 'Best Law Schools' Sponsored Content Article, Above the Law (June 6, 2016, 1:45 PM), https://perma.cc/8PTN-MFC3 (click on image titled "NEWSWEEK RAISING THE BAR - BEST LAW SCHOOLS 2016" to view the original native ad)

93 It seems likely that Seattle University and St. Thomas University also paid to be included in the "Best Law Schools 2016." Newsweek offered two price points: a higher price for "National Profile," where the school's profile would be seen by visitors from across the U.S., and the school's picture would be used in rotation to promote the section on the front page of Newsweek.com - versus a lower price for law schools that only wanted a "Regional Profile" (where the school's profile would be seen only by visitors from up to four specified states). Id. If that is correct, we would have seen Seattle University and St. Thomas University law schools in the sidebar if we had been located in one of the specified states when viewing the Newsweek website.

94 Although the U.S. News rankings of law schools is highly imperfect, they nonetheless provide a useful rough benchmark for evaluating whether any of the listed institutions qualify as one of the Best Law Schools - 2016. None of these schools are ranked in the top 10 - or top 20 - or even the top 35 law schools in the United States. And most are found closer to the bottom of the U.S. News rankings than to the top.

95 Shaun Austin \& Nic Newman, Attitudes to Sponsored and Branded Content (Native Advertising), Reuters Institute DiGital News RePORT (2015), https:/perma.cc/DS9LCK6S. 
issues, we expect the rise of native advertising will result in further declines in consumer trust.

\section{Does Intent Matter?}

Intent is an important factor in the common law of deceptive practices - including intentional and/or negligent misrepresentation. ${ }^{96}$ But, when Congress passed the FTC Act, it sought to free consumer protection from common law requirements. Instead, the FTC would judge advertising and commercial practices by their likelihood to mislead. ${ }^{97}$

For that reason, intent is not even mentioned in the FTC's policy statement on deception. ${ }^{98}$ Instead, the FTC Act effectively imposes strict liability on advertisers for deceptive advertising and commercial practices, regardless of their intent. ${ }^{99}$ Although intent is not relevant in determining whether the FTC Act was violated, "bad" intent is a factor in the design of an appropriate remedy. ${ }^{100}$ Thus, we think of intent as a

96 See generally Francis H. Bohlen, Misrepresentation as Deceit, Negligence, or Warranty, 42 Harv. L. Rev. 733 (1929); Gregory Klass, Meaning, Purpose, and Cause in the Law of Deception, 100 GEO. L.J. 449 (2012). See also RESTATEMENT (SECOND) OF TORTS $§ 525$ (1977) (imposing liability on anyone who "fraudulently makes a misrepresentation of fact, opinion, intention or law for the purpose of inducing another to act or to refrain from action in reliance upon it.")

97 FTC v. Sterling Drug, Inc., 317 F.2d 669, 674 (2d Cir. 1963) ("In order best to implement the prophylactic purpose of the statute, it has been consistently held that advertising falls within its proscription not only when there is proof of actual deception but also when the representations made have a capacity or tendency to deceive, i.e., when there is a likelihood or fair probability that the reader will be misled.")

98 See supra note 78 and accompanying text.

99 Chrysler Corp. v. FTC, 561 F.2d 357, 363 n 5 (D.C. Cir. 1977) ("An advertiser's good faith does not immunize it from responsibility for its misrepresentations; intent to deceive is not a required element for a section 5 violation."); Regina v. FTC, 322 F.2d 765, 768 (3rd Cir. 1963) ("Proof of petitioner's intention to deceive is not a prerequisite to a finding of a violation; it is sufficient that deception is possible." (citation omitted)); FTC v. Sterling Drug, Inc., 317 F.2d 669, 674 (2d Cir. 1963) ("[P]roof of intention to deceive is not requisite to a finding of violation of the statute.")

100 More specifically, the remedy that is chosen must bear a reasonable relationship to the unlawful conduct - and the more deliberate the violation, the easier it is to justify more extensive relief. See Thompson Medical Co. v. FTC, 104 F.T.C. 648, 833 (1984), aff d 791 F.2d 189 (D.C. Cir. 1986) (concluding that broad relief was justified based on "deliberateness" of Thompson's false and deceptive advertising); Sears Roebuck \& Co. v. FTC, 676 F.2d 385, 392 (9th Cir. 1982) ("Where a fair assessment of an advertiser's conduct shows a ready willingness to flout the law, sufficient cause for concern regarding further, additional violations exists. Two factors or elements frequently influence our decision - the deliberateness and seriousness of the present violation, and the violator's past record with respect to unfair advertising practices.") 
"plus-factor" —analogous to the "aggravating circumstances" that apply in criminal sentencing.

The implications are straightforward. Infomercials were created because "no one would knowingly sit down and watch a half hour commercial, [but] advertisers ingeniously realized that the public would watch a half hour commercial masquerading as a talk show." ${ }^{101}$ In like fashion, publishers, platforms, and brand owners are using native advertising because they know that people don't like (and don't pay attention to) regular advertising. The whole point of native advertising is to circumvent this resistance, by making ads look like unpaid news or editorial content. If that sounds like "intent to deceive," it is because that is exactly what is going on.

\section{E. Self-Identity and the Media Ecosystem}

How does native advertising affect the media companies, and the media ecosystem? For starters, native advertising has created new job opportunities for tech-savvy millennials to work for media companies. Publishers/platforms have created dedicated in-house native advertising units. And, publishers and platforms now have a much larger incentive to work closely with advertisers and brand owners, to ensure that native ads are seamlessly integrated with news and editorial content.

Native advertising has also triggered a broader debate over the media's self-identity. For decades, there has been a separation of the advertising and news/editorial sides of the media business - referred to, with considerable grandiosity and self-importance, as the divide between "church and state." Native advertising breaches this separation - leading to considerable existential angst among most commentators. Our findings do not cast light on this issue one way or the other - but they do make it clear that from the reader/user perspective, native advertising does, in fact, obliterate the separation between advertising and the news/editorial sides of the media business. Where that will lead, we will not hazard to guess. But, we doubt it will lead to higher status or greater public regard for the news media.

101 W.H. Ramsay Lewis, Informercials, Deceptive Advertising and the Federal Trade Commission, 19 Fordham URB. L. J. 853, 865 (1991). 


\section{F. Remedies}

What, if anything, should be done about native advertising? While it may not be possible to find a "one-size-fits-all remedy, ${ }^{102}$ it seems clear that more should be done to inform consumers. For starters, publishers and platforms should develop a system of standardized labeling. The diversity of labels, both within and across publishers and platforms is an obvious potential source of confusion. The standardized label should transparently signal the associated content is paid - ideally through the use of some combination of the words "paid" and "ad." As the FTC guidelines indicate, page layout and architecture (including borders and the use of differing typefaces) can also help differentiate paid content from news and editorials.

That said, we should be modest about what can actually be achieved with labeling strategies. In previous work, we show that Internet users don't pay attention to the labels on the search results page. ${ }^{103}$ And, evidence on the effectiveness of disclosure as a regulatory strategy is unimpressive, at best. ${ }^{104}$

Technology, implemented through user self-help, can also play a role. ${ }^{105}$ Ad blockers helped trigger the rise of native advertising. ${ }^{106}$ Perhaps the next generation of ad blockers will snuff out native advertising, triggering a further round of adaptation by publishers and platforms.

\section{G. Robustness/Further Research}

Our findings should not be seen as the last word on this subject. To minimize order effects, we used random order presentation of

Frankfurt, Kurnit, Klein + Selz, Highlights from FTC's Native Advertising Workshop: More Questions Than Answers? AdverTising LAW AlerTs (Dec. 9, 2013), https:/perma.cc/7VBF-8WZA ("Participants largely agreed that, in situations where disclosure is called for, a one-size-fits-all approach is not only undesirable, but impossible.")

103 David A. Hyman \& David Franklyn, Search Bias and the Limits of Antitrust: An Empirical Perspective on Remedies, 55 Jurimetrics 339 (2015).

104 See generally OMri Ben-SHAHAR \& CARL E. SCHNEIDER, MORE THAN YOU WANTED to KNOW: The Failure of Mandated Disclosure (2014) (discussing the failures of the mandated disclosure). See also Omri Ben-Shahar \& Carl E. Schneider, The Failure of Mandated Disclosure, 159 U. PA. L. REV. 647, 679-729 (2011).

105 See, e.g., Steven Perlberg, Meet AdDetector: The New Plug-in That Labels Native Advertising, WALL ST. J. (Aug. 20, 2014, 4:59 PM), https:/perma.cc/4Y9A-2LDA.

106 Stephen Lepitak, Yahoo boss Marissa Mayer claims that native ads will win if ad blocker use continues to rise, THE DRUM (Sep. 28, 2015, 10:11 PM), https:/perma.cc/U76S-T8PH. 
images. In unreported findings, our results were virtually identical when we limited our analysis to the first image that each respondent saw. ${ }^{107}$ However, further research will be necessary to confirm our findings are generalizable to other native ads, publishers and platforms.

\section{CONCLUSION}

In our study, most respondents were unable to identify native advertising as paid content - and they did much worse with native advertising than with "regular" advertising. Modest labeling changes materially increased the number of correct responses -- but even these improved results fell well short of those for "regular" advertising. Many of the labels used to identify native advertising are unclear. When we asked respondents to rank their preferred labels, they systematically preferred more explicit language than is currently generally employed. Our findings suggest that self-regulation is not addressing the significant risk of deception posed by native advertising.

Averaged across all of the ads, $40 \%$ of respondents who saw a native ad as the first image in the survey believed it to be an ad/paid content - compared to $37 \%$ for the survey as a whole (i.e., not limited to the first image). $84 \%$ of respondents who saw a regular ad/paid content as the first image in the survey believed it to be an ad/paid content - compared to $81 \%$ of respondents across the survey as a whole. These differences (40\% versus $37 \%$ for native ads, and $84 \%$ versus $81 \%$ for regular ads) were not statistically significant. 


\section{APPENDIX}

In Table A-1, we present basic demographic information about respondents.

\begin{tabular}{|l|c|c|}
\hline Age & Number & $\%$ \\
\hline$<20$ & 21 & $2 \%$ \\
\hline $20-29$ & 167 & $19 \%$ \\
\hline $30-39$ & 208 & $23 \%$ \\
\hline $40-49$ & 155 & $17 \%$ \\
\hline $50-59$ & 164 & $18 \%$ \\
\hline $60+$ & 181 & $20 \%$ \\
\hline & & \\
\hline Education & Number & $\%$ \\
\hline Some high school or less & 17 & $2 \%$ \\
\hline High school completed & 148 & $17 \%$ \\
\hline Some College & 256 & $29 \%$ \\
\hline Completed College & 280 & $31 \%$ \\
\hline $\begin{array}{l}\text { Some Graduate School or } \\
\text { completed Graduate School }\end{array}$ & 182 & $20 \%$ \\
\hline Other & 13 & $1 \%$ \\
\hline & & \\
\hline $\begin{array}{l}\text { Advertising/Marketing } \\
\text { Experience? }\end{array}$ & Number & $\%$ \\
\hline No & 874 & $98 \%$ \\
\hline Yes & 22 & $2 \%$ \\
\hline
\end{tabular}

